\title{
Growth and Body Nutrient Deposition of Two Broiler Commercial Genetic Lines
}

Author(s)
Marcato $\mathrm{SM}^{1,2}$
Sakomura $\mathrm{NK}^{1,3}$
Munari $\mathrm{DP}^{1}$
Fernandes $\mathrm{JBK}^{4}$
Kawauchi ÍM ${ }^{1}$
Bonato MA ${ }^{1}$
1 Post-Graduation Program in Animal Science
- FCAV/UNESP. Jaboticabal, SP.
2 Present address: Department of Animal
Science - UEM. Maringá, PR.
Department of Animal Science - FCAVI
UNESP. Jaboticabal, SP.
Aquaculture Center - FCAV/UNESP.
Jaboticabal, SP.

Mail Address

Simara Márcia Marcato

Universidade Estadual de Maringá

Centro de Ciências Agrárias

Departamento de Zootecnia, Bloco G56

Avenida Colombo, 5790 - Zona 07

87.020-900. Maringá, PR, Brazil.

E-mail: simaramm@yahoo.com.br

\section{Keywords}

Body composition, broilers, growth, Gompertz curves.

\section{ABSTRACT}

The objective of this work was to study growth and body nutrient deposition profiles of male and female Cobb and Ross broilers using Gompertz equations. A total number of 1,920 one- to 56-day-old broilers were used. A randomized experimental design in a factorial arrangement (2 strains $\times 2$ sex), with 4 replicates of 120 birds each, was applied. Diets were formulated to supply the nutrient requirements recommended by the genetic companies. A sample of birds was weekly weighed and sacrificed after 24 hours fasting. Carcasses were defeathered and weighed again. The parameters of the Gompertz equation for body weight and its components (water, ashes, protein, and fat) were estimated. An interaction $(p<0.05)$ between sex and breed was observed for mature weight $(\mathrm{Wm})(\mathrm{kg})$, growth rate (b) (daily) and time at maximum growth rate $\left(t^{*}\right)$ (day) of body weight, and body water and ash. Cobb was presented earlier growth and body protein and ash deposition. Ross strain was superior in body water deposition.

\section{INTRODUCTION}

In the last few years, the poultry industry presented a significant increase in the animal production sector. Genetic improvement was the main factor that contributed for this important development of broiler production.

Genetic companies currently apply careful processes to improve broiler performance. The selection for body weight changed the growth curve, increased feed efficiency, causing birds to reach market age earlier. However, different genotypes have different growth curves and different body compositions, which makes them have different nutritional requirements. According to Gous et al. (1999), fitting bird growth curve is the first step to predict the nutritional requirements of the different genotypes, thereby supporting the selection process, and contributing for the assessment of bird genetic potential.

Many non-linear mathematic models have been used to describe animal growth and body nutrient deposition, but some authors (Fialho, 1999; Gous et al., 1999; Macleod, 2000; Sakomura et al., 2005; Santos et al., 2005; Neme et al., 2006) indicate that the Gompertz function is the one that best describes them.

The determination of the parameters of Gompertz equations is extremely important for poultry production. In addition to predicting weight and nutrient deposition of birds at any age, these equations help to define the best market weight, and to establish specific feeding programs according to genetic line and sex, thus contributing to improve performance and to reduce production costs.

Growth curves, as determined by prediction equations, are important for the development of simulation models, which are usually used as 
Marcato SM, Sakomura NK, Munari DP, Fernandes JBK, Kawauchi ÍM, Bonato MA
Growth and Body Nutrient Deposition of Two Broiler Commercial Genetic Lines software in poultry companies. Some of these software applications are available in the market for broilers, such as $\mathrm{IGM}^{\circledR}$, Fortell Model ${ }^{\mathrm{TM}}$, Omnipro $\|^{\circledR}$ and Chickopt ${ }^{\mathrm{TM}}$ (Rostagno et al., 2006).

When determining which parameters need to be included, some considerations must be made. For instance, as feather growth prediction is extremely complex due to difficult estimation of feather loss and skin sloughing, Emmans (1995) proposes that body weight is expressed as de-feathered body, and to establish its relation with the other body components.

Gous et al. (1999) described carcass, breast and feather development, as well as protein, fat, water, and ash carcass content during a period of 1 to 16 weeks of age of birds from two different lines using the Gompertz curve. According to the live weight results, mature males were heavier $(\mathrm{Wm})$ and lower maximum growth rates (b) as compared to females. As to chemical composition of de-feathered birds, males presented higher Wm parameters for protein and water as compared to females, revealing that males took longer to reach maximum protein and water deposition rates. Nevertheless, the opposite was found for fat deposition: females took longer than males to reach maximum body fat deposition rates.

Similar results were found by Sakomura et al. (2005), who evaluated growth potential of male and female Ross broilers in terms of body weight and chemical composition. The authors observed that males presented higher growth potential, and consequently higher nutrient deposition capacity as compared to females, except for fat deposition.

The present study aimed at estimating body weight, de-feathered carcass weight, and body nutrient deposition growth parameters of two commercial broiler breeds.

\section{MATERIAL AND METHODS}

The experiment was carried out in the experimental poultry house of the Poultry Sector of the Department of Animal Science of the School of Agrarian and Veterinary Science of UNESP, Jaboticabal, SP, Brazil. A total number of 1,920 male and female Ross 308 and Cobb 500 one-day-old chicks was used. Birds were housed in pens with a capacity of $10 \mathrm{birds} / \mathrm{m}^{2}$, equipped with tube feeders and bell drinkers. Total experimental period was 56 days.

Chicks were individually weighed, and were designated to the treatments in groups of similar average weight. A completely randomized experimental design in a $2 \times 2$ ( 2 breeds $\times 2$ sexes) arrangement, with 4 replicates of 120 birds each (16 experimental units), was applied.

During the experimental period, birds were vaccinated for IBD at 7, 21 and 35 days of age, and for Infectious Bronchitis and Newcastle Disease at 14 days of age.

Water and feed were offered ad libitum. Feeds were based on corn and soybean meal, and formulated to supply the birds' nutritional requirements according to the recommendations of the genetic companies for each rearing phase. Feeds contained $3010 \mathrm{kcal} \mathrm{ME} / \mathrm{kg}$ and $22 \%$ de CP (1-7 days); $3150 \mathrm{kcal} \mathrm{ME} / \mathrm{kg}$ and $21,50 \%$ CP (8-28 days); $3200 \mathrm{kcal} \mathrm{ME} / \mathrm{kg}$ and $20 \% \mathrm{CP}$ (29-49 days) and $3245 \mathrm{kcal} \mathrm{ME} / \mathrm{kg}$ and 18\% CP (50-56 days).

All birds were weekly weighed to calculate average body weight, based on which birds representing experimental unit (EU) average weight were selected. In the first week, 10 birds per EU (total $=160$ birds) were selected and sacrificed. In weeks 2 and 3, 5 birds per EU (total $=80$ birds), and 4 birds per EU (total $=64$ birds) were selected and sacrificed. Before sacrifice, birds were submitted to 24-h fasting to allow complete emptying of the gastrointestinal tract. Birds had access to water during fasting. After fasting, birds were individually weighed to obtain fasted weight, and sacrificed by $\mathrm{CO}_{2}$ asphyxia in compliance with international ethics criteria.

De-feathered carcasses (whole bird with no feathers) were individually weighed, placed in duly identified plastic bags, and frozen for later processing and sample collection. Carcasses were cut with a saw and ground in an industrial meat grinder in order to produce homogenous samples. Out of the total sample, a 60 to $80 \mathrm{~g}$ subsample was taken, placed in a disposable plastic Petri dish, and freeze-dried at $-50^{\circ} \mathrm{C}$ in a Thermo VLP200 apparatus to obtained pre-dried matter. Samples were then ground in a IKA microgrinder, and submitted to the laboratory for nitrogen, ether extract, dry matter, and ashes determination. The applied methodologies are described in Silva \& Queiroz (2002).

Growth curve parameters for fasted body weight, de-feathered bird weight, and body nutrient deposition, obtained weekly, were estimated using the following Gompertz equation (1825): $W_{t}=W_{m}$. exp .(- exp . (- b $\left.\left.\left(t-t^{*}\right)\right)\right)$, where: $W_{t}=$ weight $(g)$ of the bird at time $t$, expressed as a function of $W_{m} ; W_{m}=$ mature weight (g); $b=$ growth rate (daily); $t^{*}=$ time (days) when growth rate is maximal. Based on the estimated 
equations, growth rates ( $\mathrm{g} /$ day) were calculated as a function of time (t), using the Gompertz equations derivate.

In addition to growth parameters, the logarithm allometric relations were calculated. The dependent variable is the body component quantity (protein, fat, water, ashes, and energy), and the independent variable is body protein weight. The following equation was applied: $\log _{10}$ (component weight) $=a+b \log _{10}$ $(C P)$, where component weight is the total body quantity, and $C P$ is body protein weight. The parameters were analyzed using the option Separate lines, estimate differences from level of the procedure Simple Linear Regression with Groups of the software GenStat, $10^{\text {th }}$ Edition (2007),

The parameters indicated in the Gompertz equation were submitted to analysis of variance using the procedure ANOVA of SAS (2001). Means were compared by the $F$ test $(5 \%)$. The regression equations and the Gompertz functions used to describe growth were separately fit to each sex and breed data using SAS (2001).

\section{RESULTS AND DISCUSSION}

Interactions between breed and sex were significant $(p<0,05)$ for all parameters of the Gompertz equation for fasted live weight, de-feathered carcass weight, and water and ashes deposition. The details of the breed vs. sex interaction are shown in Table 1. Cobb females and Ross males were different from Ross females and Cobb males for fasted live weight and de-feathered carcass weight.

Cobb males were different $(p<0,05)$ from Ross males and Cobb females for all Gompertz equation parameters in terms of carcass water content. However, as for ashes, Ross males were different than Cobb males and Ross females for $\mathrm{Wm}, \mathrm{b}$ and $t^{*}$.

Mature weight (Wm), according to Duarte (1975), represents genetic growth potential and the effect of genes that determines growth, making this asymptotic measure a parameter resulting from previous growth stages. Ross females and Cobb males presented higher Wm values, but had lower and similar maturity rate (b) values, respectively, for fasted live weight and defeathered carcass weight, which is possible due to the selection for maximum growth rate. This means that growth rates are different between breeds and sexes, reflecting the differences in nutritional requirements and rearing management of the studied birds.

According to Silva (1998), for the same mature weight, low maturity rate (b) values indicates that the birds reaches maturity later. In the present experiment, Cobb males presented the lowest $b$ values for water deposition, and Ross males, for ashes deposition, and both reached maximum growth age $\left(t^{\star}\right)$ later.

rowth rate increases with bird age up to a limit, when rate is maximum, and then gradually decreases. This is called the inflection point, where the concave curve becomes convex, and corresponds of age at maximum growth $\left(\mathrm{t}^{*}\right)$ (Kessler, 2000). According to Duarte (1975), the inflection point of the Gompertz model is fixed, corresponding to $37 \%$ of the $\mathrm{Wm}$ value. The same occurred in the present study: the inflection point varied between 36 and $37,7 \%$ of the $\mathrm{Wm}$ value for fasted live weight and de-feathered carcass weight.

As shown in Figure 1 and Table 2, growth rates for fasted live weight and de-feathered carcass weight were different between breeds. Cobb birds presented higher growth rates up to 35 days, and thereafter,

\begin{tabular}{|c|c|c|c|c|c|c|}
\hline \multirow[t]{3}{*}{ Breeds } & Males & Females & Males & Females & Males & Females \\
\hline & \multicolumn{2}{|c|}{$W m^{1}(g)$} & \multicolumn{2}{|c|}{$b^{2}$ (daily) } & \multicolumn{2}{|c|}{$t^{* 3}$ (days) } \\
\hline & \multicolumn{6}{|c|}{ Fated live weight } \\
\hline Ross & $6627,84 \mathrm{~A}$ & $4657,74 \mathrm{~B}$ & $0,042 \mathrm{~B}$ & $0,0468 \mathrm{Ab}$ & $39,19 \mathrm{~A}$ & $34,41 \mathrm{Ba}$ \\
\hline \multicolumn{7}{|c|}{ DE-Feathered carcass weight } \\
\hline Ross & $6351,55 \mathrm{~A}$ & $4319,04 \mathrm{~B}$ & 0,042 B & $0,042 \mathrm{~B}$ & $39,24 \mathrm{~A}$ & $33,95 \mathrm{~B}$ \\
\hline Cobb & $6715,50 \mathrm{~A}$ & 3999,10 B & $\begin{array}{r}0,041 \mathrm{~B} \\
\text { Wate }\end{array}$ & $0,041 B$ & $40,34 \mathrm{~A}$ & $31,80 \mathrm{~B}$ \\
\hline Ross & $3215,70 \mathrm{Ab}$ & 2269,96 B & $0,052 \mathrm{Ba}$ & $0,057 \mathrm{~A}$ & $32,73 \mathrm{Ab}$ & $28,96 \mathrm{~B}$ \\
\hline Cobb & 4027,97 Aa & 2342,57 B & $\begin{array}{r}0,045 \mathrm{Bb} \\
\text { Ashe }\end{array}$ & $0,054 \mathrm{~A}$ & $37,28 \mathrm{Aa}$ & $29,21 B$ \\
\hline Ross & $360,34 \mathrm{Aa}$ & $115,06 \mathrm{~B}$ & $0,038 \mathrm{Bb}$ & $0,061 \mathrm{Ab}$ & $52,63 \mathrm{Aa}$ & $29,15 B$ \\
\hline Cobb & $173,83 \mathrm{Ab}$ & 87,35 B & 0,051 Ba & 0,082 Aa & $34,12 \mathrm{Ab}$ & $23,85 B$ \\
\hline
\end{tabular}

$1-W m(k g)=$ mature weight. $2-b$ (daily) = growth rate. $3-t^{*}$ (day) = time when growth is maximal* Weight of the de-feathered carcass of bird fasted for 24 h.. ab Means in the same column followed by different small letters are different $(p<0,05)$ by the $F$ test.AB - Means in the same row followed by different capital letters are different $(p<0,05)$ by the $F$ test. 
Fasted live weight

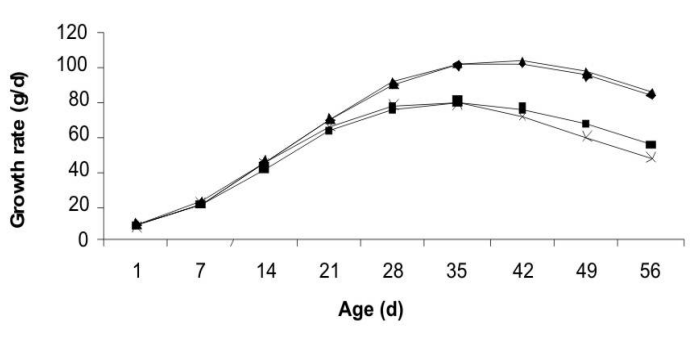

$\rightarrow$ Male Ross $\_$Female Ross $\_$Male Cobb $\_$Female Cobb

Protein deposition rate

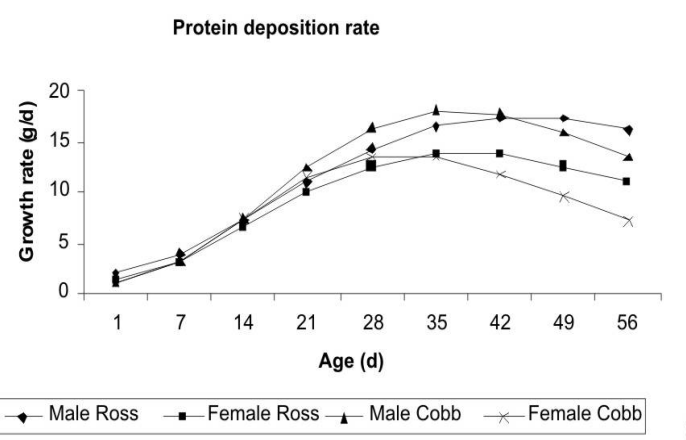

- Male Ross $\rightarrow$ Female Ross $\_$Male Cobb $\leftarrow$ Female Cobb
De-feathered carcass weight

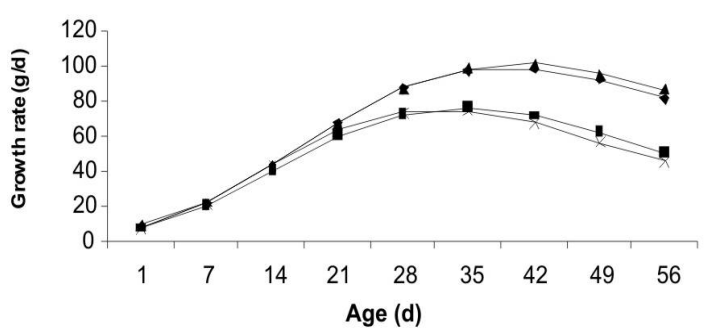

(a)

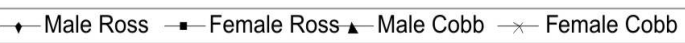

(b)

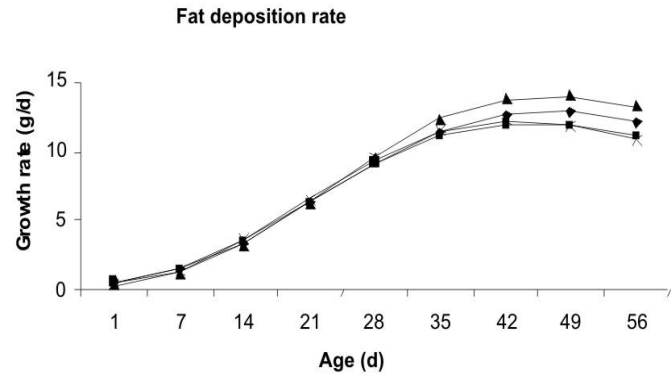

(c)

$\rightarrow$ Male Ross $\rightarrow$ Female Ross $\_$Male Cobb $\nrightarrow$ Female Cobb

Figure 1 - Growth rates of fasted live weight (a), de-feathered carcass weight (b), and protein (c) and fat (d) deposition in male and females Cobb and Ross broilers.

Table 2 - Growth rates of fasted live weight, de-feathered carcass weight*, and protein, fat, water, and ashes deposition in male and females Cobb and Ross broilers.

\begin{tabular}{|c|c|c|c|c|c|c|c|c|c|c|c|c|}
\hline \multirow{3}{*}{$\begin{array}{l}\text { Age } \\
\text { (days) }\end{array}$} & \multirow{2}{*}{\multicolumn{2}{|c|}{$\begin{array}{l}\text { Live weight } \\
\text { (g/d) }\end{array}$}} & \multirow{2}{*}{\multicolumn{2}{|c|}{$\begin{array}{l}\text { De-feathered } \\
\text { weight }(g / d)\end{array}$}} & \multirow{2}{*}{\multicolumn{2}{|c|}{ Protein }} & \multicolumn{6}{|c|}{ Deposition $(\mathrm{g} / \mathrm{d})$} \\
\hline & & & & & & & \multicolumn{2}{|c|}{ Fat } & \multicolumn{2}{|c|}{ Water } & \multicolumn{2}{|c|}{ Ashes } \\
\hline & Males & Females & Males & Females & Males & Females & Males & Females & Males & Females & Males & Females \\
\hline \multicolumn{13}{|c|}{ ROSS } \\
\hline 1 & 11,60 & 10,73 & 8,76 & 7,96 & 1,88 & 1,26 & 0,55 & 0,54 & 4,99 & 4,81 & 0,08 & 0,15 \\
\hline 7 & 24,90 & 23,73 & 21,04 & 19,93 & 3,88 & 3,09 & 1,50 & 1,52 & 14,40 & 13,91 & 0,28 & 0,57 \\
\hline 14 & 47,00 & 44,12 & 42,63 & 39,99 & 7,18 & 6,28 & 3,50 & 3,58 & 31,48 & 29,09 & 0,79 & 1,42 \\
\hline 21 & 71,69 & 64,14 & 66,81 & 59,86 & 10,91 & 9,77 & 6,25 & 6,36 & 48,67 & 41,98 & 1,65 & 2,23 \\
\hline 28 & 92,91 & 77,82 & 86,50 & 72,64 & 14,25 & 12,49 & 9,12 & 9,12 & 59,10 & 47,19 & 2,73 & 2,58 \\
\hline 35 & 106,33 & 82,66 & 97,16 & 75,85 & 16,54 & 13,80 & 11,39 & 11,15 & 60,64 & 44,86 & 3,78 & 2,44 \\
\hline 42 & 110,64 & 79,64 & 98,19 & 71,14 & 17,52 & 13,71 & 12,65 & 12,08 & 55,34 & 38,08 & 4,57 & 2,03 \\
\hline 49 & 107,04 & 71,41 & 91,73 & 61,78 & 17,30 & 12,58 & 12,84 & 11,95 & 46,53 & 29,96 & 4,96 & 1,55 \\
\hline 56 & 97,97 & 60,75 & 80,83 & 50,78 & 16,17 & 10,89 & 12,16 & 11,05 & 36,96 & 22,40 & 4,97 & 1,12 \\
\hline \multicolumn{13}{|c|}{ СОВB } \\
\hline 1 & 10,33 & 10,22 & 9,39 & 7,99 & 1,06 & 0,92 & 0,37 & 0,48 & 5,70 & 5,91 & 0,21 & 0,07 \\
\hline 7 & 23,96 & 24,53 & 21,67 & 20,91 & 3,15 & 3,07 & 1,21 & 1,47 & 14,43 & 15,21 & 0,64 & 0,54 \\
\hline 14 & 47,67 & 47,20 & 42,89 & 42,39 & 7,37 & 7,23 & 3,23 & 3,64 & 29,99 & 29,61 & 1,51 & 1,71 \\
\hline 21 & 74,52 & 68,22 & 66,74 & 62,43 & 12,34 & 11,35 & 6,30 & 6,60 & 47,04 & 41,50 & 2,46 & 2,55 \\
\hline 28 & 97,16 & 80,42 & 86,67 & 73,54 & 16,27 & 13,55 & 9,65 & 9,50 & 60,08 & 46,43 & 3,11 & 2,50 \\
\hline 35 & 110,54 & 82,00 & 98,25 & 74,09 & 18,07 & 13,44 & 12,37 & 11,51 & 66,03 & 44,53 & 3,28 & 1,92 \\
\hline 42 & 113,49 & 75,41 & 100,57 & 66,91 & 17,74 & 11,77 & 13,85 & 12,28 & 65,01 & 38,41 & 3,05 & 1,29 \\
\hline 49 & 107,86 & 64,42 & 95,34 & 55,97 & 15,94 & 9,47 & 14,03 & 11,93 & 59,08 & 30,82 & 2,61 & 0,80 \\
\hline 56 & 96,74 & 52,22 & 85,31 & 44,37 & 13,44 & 7,20 & 13,18 & 10,80 & 50,63 & 23,53 & 2,10 & 0,48 \\
\hline
\end{tabular}

1- $\mathrm{M}=$ males, $\mathrm{F}=$ females. The highest growth rates are shown in bold letters.

lower rated as compared to Ross birds. These results indicate Cobb broilers should be slaughtered between 35 and 42 days of age, but Ross broilers, at an older age.

Table 3 shows that there was no interaction between breed ad sex ( $p>0,05)$, for Gompertz equation parameter estimated values for protein and fat deposition. Cobb broilers presented earlier protein deposition as compared to Ross broilers, as the former presented higher $(p<0,05)$ b value, and consequently, lower $(p<0,05) t^{*}$ value. These results show that these two breeds present different protein deposition rates, 


\section{Marcato SM, Sakomura NK, Munari DP, Fernandes JBK, Kawauchi ÍM, Bonato MA}

which is consistent with Kesller (2000), who reported the protein, i.e., lean tissue, deposition is highly controlled by genetics.

In terms of fat deposition, there was no difference $(P>0,05)$ between breeds for $W m$ and $t *$, but maturity rate $(b)$ was different $(p<0,05)$. The opposite happened for sex: there was no difference $(p>0,05) b$, but all other parameters were different $(p<0,05)$ between sexes. Despite no significant differences between breeds were detected for fat deposition, Ross birds reached maximum growth 4 days later as compared to Cobb birds, which can be explained by the fact that Cobb presented higher fat deposition rate at maturity as compared to Ross. According to Michelan Filho (1986), bird carcass fat content is heritable. However, other factors contribute to fat deposition in animals, such diet and environmental conditions.

According to Gous et al. (1999) and Sakomura et al. (2005), fat deposition rates at maturity are higher in males as compared to females. However, the opposite was observed in the present study, where females presented higher $b$ values than males. Males presented higher fat deposition rates than females due to their higher gain potential. The differences between the results of our study and those found in literature may have been influenced by age at slaughter. In the present work, birds were slaughtered at 56 days of age, whereas in the studies of Gous et al. (1999) and Longo (2000), birds were slaughtered with approximately 120 days, with females presenting higher fat deposition rates as compared to males. Gous et al. (1999) indicated that in females, fat deposition rate significantly increased after 56 days of age, and suggest that this additional fat deposition after this period allows birds to prepare for future egg laying.

In our study, fat deposition occurred later than protein deposition, for both breeds and sexes. According to Kessler (2000), birds deposit more body fat as they age. This fact is related to the achievement of maturity and occurs in most animals. Protein (lean tissue) deposition is mostly controlled by genetics, and therefore there is a limit for its daily deposition, independently from intake. On the other hand, fat deposited in any development phase is directly related to the amount of energy available.

As shown in Figure 1 and Table 2, Ross birds reached maximum protein deposition rate a week later as compared to Cobb. The highest protein deposition rates were found 35- and 42-day-old males and 28- and 35day-old females of the breeds Cobb and Ross,
Growth and Body Nutrient Deposition of Two Broiler Commercial Genetic Lines

respectively, indicating higher lean tissue accretion potential of males and Cobb birds. According to Albino et al.(2000), females present lower lean tissue accretion and higher body fat content, and these differences tend to intensify as broilers age.

Cobb broilers deposited protein earlier, but after the inflection point, their protein deposition rate becomes slower, whereas Cobb was faster. According to Kessler et al. (2000), the higher and the longer is the protein deposition plateau, the more efficient is the bird to produce meat, and the better will be its carcass composition.

Griffiths et al. (1977) commented that there are differences in abdominal fat deposition among breeds, and the highest fat deposition usually occurs in breeds with the highest weight gain potential. As shown in Figure 1 and Table 2, fat deposition was higher in Cobb as compared to Ross birds.

A relationship was found between water and fat deposition: when water deposition starts to decline, fat deposition increased.

Cobb birds presented earlier fasted live weight, defeathered carcass weight, protein and ash deposition growth rates, whereas Ross had earlier water deposition rates, but both had similar fat deposition rates. These results show that there are difference in growth between breeds, despite both being selected for high growth rate. Cobb presented high growth rate in the beginning, whereas Ross was slower in the beginning, but faster at the end. The selection process for body weight may have contributed for these differences. Despite the differences in growth rate and nutrient deposition, weight gain at 42, 49, and 56 days of age were not significantly different between breeds (Marcato et al., 2005).

The importance of the use of mathematic models to obtain growth and body composition estimates of birds of different breeds and sexes, in addition to help to estimate nutritional requirements, also contributes to establish the optimal market age, supplying the demands of the poultry companies and reducing production costs.

Growth and body nutrient deposition can also be estimated by allometric equations. These equations determine body nutrients as a function protein weight. The use of protein weight in allometric ratios provides higher precision to the equations, as differences between sexes and breeds are often small.

The allometric equations for fat, ashes, and water weight as a function of protein weight are presented 


\section{Marcato SM, Sakomura NK, Munari DP, Fernandes JBK, Kawauchi ÍM, Bonato MA}

\section{Growth and Body Nutrient Deposition of Two Broiler}

Commercial Genetic Lines

\begin{tabular}{|c|c|c|c|c|c|c|c|c|c|}
\hline & \multicolumn{3}{|c|}{$W m^{1}(g)$} & \multicolumn{3}{|c|}{$b^{2}$ (daily) } & \multicolumn{3}{|c|}{$t^{* 3}$ (days) } \\
\hline & Males & Females & Mean & Males & Females & Mean & Males & Females & Mean \\
\hline Breeds & & & & & Proteína & & & & \\
\hline Ross & 1308,61 & 865,69 & $1087,2 a$ & 0,037 & 0,044 & $0,040 \mathrm{~b}$ & 44,02 & 37,88 & $40,95 \mathrm{a}$ \\
\hline Cobb & 1041,95 & 666,68 & 854,3 b & 0,047 & 0,056 & $0,051 \mathrm{a}$ & 37,19 & 31,02 & $34,10 \mathrm{~b}$ \\
\hline Mean & $1175,28 \mathrm{~A}$ & $766,18 B$ & & 0,037 & 0,044 & $0,040 \mathrm{~b}$ & 44,02 & 37,88 & $40,95 \mathrm{a}$ \\
\hline \multicolumn{10}{|c|}{ Gordura } \\
\hline Ross & 907,16 & 810,91 & 859,0 & 0,039 & 0,041 & $0,039 \mathrm{~b}$ & 46,78 & 44,51 & 45,64 \\
\hline Cobb & 930,73 & 780,78 & 855,7 & 0,041 & 0,043 & $0,042 a$ & 46,47 & 42,99 & 44,73 \\
\hline Mean & $918,95 \mathrm{~A}$ & 795,85 B & & 0,040 & 0,041 & $46,62 \mathrm{~A}$ & $43,75 \mathrm{~B}$ & & \\
\hline
\end{tabular}

$1-\mathrm{Wm}(\mathrm{kg})=$ mature weight. $2-\mathrm{b}$ (daily) $=$ growth rate. $3-\mathrm{t}^{*}($ day $)=$ time when growth is maximal* Weight of the de-feathered carcass of bird fasted for $24 \mathrm{~h} .{ }^{\text {ab }}$ Means in the same column followed by different small letters are different $(p<0,05)$ by the $F$ test. ${ }^{A B}$ Means in the same row followed by different capital letters are different $(p<0,05)$ by the $F$ test.

\begin{tabular}{|c|c|c|c|c|c|}
\hline \multirow[t]{2}{*}{ Component(g) } & \multirow[t]{2}{*}{ Parameter ${ }^{2}$} & \multicolumn{2}{|c|}{ Males } & \multicolumn{2}{|c|}{ Females } \\
\hline & & Cobb & Ross & Cobb & Ross \\
\hline \multicolumn{6}{|c|}{ Carcass (g) } \\
\hline \multirow[t]{2}{*}{ Water } & a & $1,788^{\text {a }}$ & $1,795^{a}$ & $1,728^{a}$ & $1,848^{\text {a }}$ \\
\hline & b & $0,925^{a}$ & $0,921^{\text {a }}$ & $0,929^{a}$ & $0,910^{a}$ \\
\hline \multirow{2}{*}{ Ether extract } & a & $-1,483$ a & $-1,770^{b}$ & $-1,767 b$ & $-1,837 b$ \\
\hline & b & $1,164^{b}$ & $1,210 a b$ & $1,243^{\text {a }}$ & $1,263^{a}$ \\
\hline \multirow[t]{2}{*}{ Ashes } & a & $-1,167^{a}$ & $-1,182^{a}$ & $-0,981^{a}$ & $-1,209$ a \\
\hline & b & $0,916^{\mathrm{a}}$ & $0,923^{\text {a }}$ & $0,865^{\mathrm{a}}$ & 0,923 а \\
\hline
\end{tabular}

1- ${ }^{a-b}$ Within each component, values followed by different letters in the same row are different $(P>0,05) .{ }^{1}$ Natural logarithm $\left(\right.$ Neperian). ${ }^{2} a=$ regression constant; $b=$ coefficient of the regression slope.

in Table 4. According to these equations, there were no breed or sex differences for water and ash body weight. Body fat weight was different for Cobb males as compared to Ross males and females and to Cobb females.

The results obtained in the present study demonstrate that growth curves and nutrient deposition was different between Ross and Cobb and males and females. This suggests that Cobb and Ross must apply different feeding programs to allow maximum growth. The obtained data are consistent with Neme (2006), who asserts that the knowledge of the body weight is not sufficient to determine bird requirements, and that body composition must be evaluated to improve feeding programs.

\section{CONCLUSIONS}

Growth rates and body nutrient deposition were different for the studied breeds and sexes. Cobb birds presented earlier growth and protein and ash deposition, whereas Ross birds had earlier water deposition.

\section{REFERENCES}

Albino LFT, Nascimento AH, Valério SR. Níveis de energia da dieta e da temperatura ambiente sobre a composição da carcaça em frangos (músculo e gordura). Anais da Conferência Apinco de Ciência e Tecnologia Avícolas; 2000; Campinas, São Paulo. Brasil: FACTA; 2000. p.62-79

Duarte FAM. Estudo da curva de crescimento de animais da raça Nelore, através de cinco modelos estocásticos [tese]. Ribeirão Preto (SP): Faculdade de Medicina de Universidade de São Paulo; 1975.

Emmans GC. Problems in modelling the growth of poultry. World's Poultry Science Journal 1995; 51:77-89.

Fialho FB. Interpretação da curva de crescimento de Gompertz [Comunicado Técnico 237]. Concórdia: Embrapa-CNPSA; 1999.

Gompertz B. On the nature of the function expressive of the law of human mortality and on a new method of determining the value of life contingencies. Philosophical Transactions of the Royal Society of London 1825; 115:513-85.

Gous RM, Moran Jr ET, Stilborn HR, Bradford GD, Emmans GC. Evaluation of the parameters needed to describe the overall growth, the chemical growth, and the growth of feathers and breast muscles of broilers. Poultry Science 1999; 78:812-21.

Griffiths L, Leeson S, Summers JD. Studies on abdominal fat with four commercial strains of male broiler chicken. Poultry Science 1977; 57:1198-1203.

Kessler AM, Snizek PN, Brugalli I. Manipulação da quantidade de gordura na carcaça de frangos. In: Anais da Conferência Apinco de Ciência e Tecnologia Avícolas; 2000; Campinas, São Paulo.Brasil. Campinas: FACTA; p.107-133.

Longo F. Estudo do metabolismo energético e do crescimento de 


\section{Marcato SM, Sakomura NK, Munari DP, Fernandes JBK, Kawauchi ÍM, Bonato MA}

frangos de corte [dissertação]. Jaboticabal (SP): Faculdade de Ciências Agrárias e Veterinária, Universidade Estadual Paulista; 2000.

Macleod MG. Modelling the utilization of dietary energy and amino acids by poultry. In: Theodorou MK, France J, editor. Feeding systems and feed evaluation models. Wallingford: CABI Publishing; 2000. p.393-412.

Marcato SM, Sakomura NK, López CAA, Piva GH, Kawauchi IM, Bonato MA. Desempenho e rendimento de carcaça e partes de duas linhagens de frangos de corte. Revista Brasileira de Ciência Avícola 2005; (Supl.7):180.

Michelan Filho T. Seleção para diminuição do conteúdo de gordura em frangos. Concórdia: EMBRAPA/CNPSA; 1986.

Neme R, Sakomura NK, Fukayama EH, Freitas ER, Fialho FB, Resende KT, Fernandez JBK. Curvas de crescimento e deposição dos componentes corporais de aves de postura de diferentes linhagens. Revista Brasileira Zootecnia 2006; 35:1091-1100.

Payne RW, Harding SA, Murray DA, Soutar DM, Baird DB, Welham SJ, Kane AF, Gilmour AR, Thompson R, Webster R, Tunnicliffe Wilson G. Guide to genStat release 10: statistics. Oxford: VSN International; 2007.

Rostagno H, Albino LFT, Páez BLE, Rodrigues C. Uso de proteína ideal para formular dietas de frangos de corte. Seminário Técnico Ajinomoto Biolatina; 2006 dez 01; Campinas, São Paulo. Brasil. Campinas: FACTA; 2006.

Sakomura NK, Longo F, Rondon EO, Rabello CBV, Ferraudo AS. Modeling energy utilization and growth parameter description for broiler chickens. Poultry Science 2005; 84:1363-1369.

Santos A, Sakomura NK, Freitas ER, Fortes CMSá, Carrilho ENVM, Fernandez JBK. Estudos do crescimento, desempenho, rendimento de carcaça e qualidade de carne de três linhagens de frangos de corte. Revista Brasileira Zootecnia 2005; 34:1589-1598.

Silva AM da. Parâmetros genéticos para peso e perímetro escrotal de machos e características reprodutivas e de crescimento de fêmeas, na raça Canchim [dissertação]. Jaboticabal (SP): Faculdade de Ciências Agrárias e Veterinárias, Universidade Estadual Paulista Jaboticabal; 1998.

Statistical Analyses System. SAS Version Release 8.2. for Windows [CD ROM]; 2001.

Silva DJ, Queiroz AC. Análise de alimentos: métodos químicos e biológicos. 3.ed. Viçosa: Editora UFV; 2002. 